\title{
Social Support Terhadap Work-Life Balance Pada Karyawan
}

\author{
Mahda Nurhabiba ${ }^{1}$ \\ Fakultas Psikologi, Universitas Muhammadiyah Malang \\ e-mail: ${ }^{1 m a h d a n h @ g m a i l . c o m ~}$
}

\begin{abstract}
Work-life balance is a method that uses to help an employees reduce the conflict which unbalanced dual role. An individual needs to balance between his personal life and his work. Work-life balance in an employee is very important, while social support can be something that can encourage employees to carry out their obligations. This study aim to determined the effect of social support on work-life balance on employees. Research subjects 100 employees at PT. PLN PERSERO using quota sampling technique. Data collection used a scale of social support and work-life balance, data analysis used simple linear regression. Sig value Regression of 0.000 $<0.05$ shows the result that there is a significant influence between social support and work-life balance on employees. Social support contributes $24.5 \%$ to work-life balance. The results of this study provide evidence that a hypothesis stating that there is an influence between social support towards work-life balance is accepted. So with the proven hypothesis explaining that social support is one of the work-life balance factors.
\end{abstract}

KEYWORDS Work-life balance, social support, employee

CITATION Nurhabiba, M. (2020). Social support terhadap work-life balance pada karyawan. Cognicia, 8, (2). 277-295.

Karyawan bekerja semata-mata untuk mencari rezeki. Bonusnya adalah karir, ilmu yang tiada batasnya serta pengalaman-pengalaman yang berharga. Kadang jika passion bekerja kita sesuai dengan jobdesk kita bisa lupa jam kerja. Akibatnya, waktu kita dalam sehari 50\% dihabiskan di tempat bekerja sehingga waktu kita untuk keluarga dan kehidupan sosial di lingkungan tempat tinggal jadi berkurang. Kondisi ini diartikan dengan work life balance, mungkin istilah ini sudah tidak asing dalam dunia kerja. Work life balance adalah keseimbangan waktu kerja dengan kehidupan di luar dunia kerja seperti waktu bersama keluarga, teman bahkan diri sendiri.

Terdapat hasil riset yang menunjukkan 70\% karyawan mengeluhkan jam kerja dengan alasan durasi bertemu keluarga menjadi lebih singkat. Penulis sendiri pernah mengeluhkan jam kerja di perusahaan sebelumnya bekerja. Bergerak di bidang distribusi dan marketing, rata-rata jam kerja sehari bisa 10-12 jam. Hal ini tentu saja banyak faktor salah satunya adalah tuntutan perusahaan dan beban kerja yang cukup tinggi. Mungkin fenomena ini tidak hanya penulis sendiri yang mengalami dan masih banyak contoh rendahnya work life balance di perusahaan.

Salah satu faktor penting yang harus diperhatikan oleh perusahaan dalam mencapai tuntutan kerja tersebut adalah faktor sumber daya manusia (Artadi, 2015). Manusia sebagai penggerak perusahaan merupakan faktor utama karena eksistensi perusahaan tergantung pada manusia-manusia yang terlibat di belakangnya. Untuk dapat mencapainya, diperlukan sumber daya manusia yang kompeten dalam melaksanakan tugasnya. Sehingga, perusahaan 
perlu memberikan fokus terhadap kondisi pekerjanya dalam menyelesaikan pekerjaan yang diberikan perusahaan.

Namun, dalam perjalanan kerjanya sebagian besar orang mulai memperhatikan hal lain selain untuk bekerja (Mariati, 2013). Baik itu seperti halnya tentang kebutuhan untuk dihargai, membentuk ketertarikan sosial, merasa kompeten di kehidupan kerja, serta tentang ketidak-seimbangan antara kehidupan dan beban kerja yang dikerjakannya untuk perusahaan seperti misalnya, target penyelesaian tugas yang mendesak sehingga terkadang harus sampai dibawa pulang ke rumah, rapat kerja hingga larut malam, serta perjalanan bisnis ke luar kota yang akhirnya membuat kebutuhan dengan keluarga, lingkungan, maupun pemenuhan untuk pribadi menjadi terganggu.

Pada kenyataannya terkadang sebuah organisasi atau perusahaan lebih memfokuskan tuntutannya saja terhadap para pekerjanya dan sebaliknya kurang bisa menyusun dan membagi tuntutan yang datang dari setiap individu yang bekerja dalam memenuhi kebutuhan kerja mereka (Prawira, 2007). Hal ini diketahui dari wawancara dengan perwakilan karyawan bahwa terlihat kesenjangan yang muncul dalam kehidupan kerja pada perusahaan yang berada di Kota Malang. Dimana selain menjalankan pekerjaanya sebagai salah satu pekerja mereka dituntut pula untuk dapat mengembangkan kualitas kerja mereka. Perubahan beban kerja tersebut pada kenyataannya juga tidak diiringi dengan hasil kerja yang mencukupi dan juga istirahat yang cukup dikarenakan kebanyakan tugas dari pekerjaan mereka tidak jarang dikerjakan saat istirahat dan juga di rumah. Pada kondisi kehidupan kerja tersebut, maka dapat dilihat divisi penjualan ini memiliki kemungkinan stres dalam bekerja.

Keseimbangan kehidupan kerja sendiri adalah bagaimana seseorang mampu untuk menyeimbangkan antara tuntutan pekerjaan dengan kebutuhan pribadi dan keluarganya (Schermerhorn, 2005). Menurut Greenhaus, Collins, dan Shaw (2002), balance pada umumnya dipandang sebagai tidak adanya konflik. Tetapi apabila dihubungkan dan dimasukkan kedalam pengertian work-life balance, keseimbangan atau balance disini berasal dari efektivitas (berfungsi baik, produktif, sukses) dan dampak positif (memuaskan, bahagia) baik untuk pekerjaan ataupun peran keluarga (Direnzo, 2010).

Setiap orang membutuhkan keseimbangan hidup yaitu antara kehidupan pribadi dan kerja (Work-Life Balance). Jika keseimbangan tidak terpenuhi, maka dapat mengurangi produktifitas dan menyebabkan kejenuhan. Cieri, Holmes, Abot dan Pettit (2002) mendefinisikan worklife balance WLB) sebagai keseimbangan antara pekerjaan atau tangung jawab di tempat kerja dan di rumah. Permasalahan WLB terjadi ketika individu tidak bisa menjaga keseimbangan antara kehidupan pribadi dan pekerjaannya, yang akibatnya menimbulkan gangguan medis dan psikologis. Salah satu gangguan psikologis adalah stres, seseorang mudah terserang penyakit terutama jantung dan stroke.

Di sisi lain, pemasalahan worklife balance juga menjadi isu yang penting bagi manajemen di berbagai perusahaan. Adanya perhatian perusahaan terhadap karyawannya akan mendorong karyawan untuk bekerja keras tanpa memperhatikan bagaimana kebutuhan karyawan juga harus dipenuhi sehingga secara tidak langsung akan memberi efek jangka panjang bagi perusahaan, yaitu produktivitas menurun. Clutterbuck (2003) menyatakan ada beberapa permasalahan yang muncul akibat dari ketidakmampuan manajemen perusahaan dalam menerapkan worklife balance pada karyawan, diantaranya: meningkatnya absen pada karyawan, kegagalan dalam mengembangkan potensi karyawan, kurangnya inisiatif dan kreativitas, pelayanan yang buruk terhadap konsumen, perilaku 
karyawan yang buruk, rendahnya motivasi dan komitmen.

Perusahaan yang secara aktif mendorong keseimbangan yang baik antara pekerjaan dan keluarga akan memiliki angka absensi yang lebih kecil, kesejahteraan dan produktivitas kerjapun meningkat. Karyawan akan mendapat keuntungan dengan adanya keseimbangan antara pekerjaan dan tanggung jawabnya di rumah, artinya karyawan merasa tidak ada yang dikorbankan antara pekerjaan atau tanggung jawab keluarga. Oleh karena itu, suatu organisasi penting untuk menerapkan aturan mengenai worklife balance dalam memberikan kepuasan kerja, meningkatkan komitmen karyawan, serta mengurangi stres kerja pada karyawan.

Adapun beberapa hal penting yang sangat berhubungan dengan program work-life balance bagi perusahaan menurut para ahli, antara lain: (1) mengurangi tingkat ketidakhadiran dan keterlambatan; (2) meningkatkan produktivitas; (3) adanya komitmen dan loyalitas karyawan; (4) meningkatnya retensi pelanggan; dan (5) berkurangnya turnover karyawan. Sedangkan bagi karyawan, manfaat program work-life balance antara lain: (1) meningkatnya kepuasan kerja; (2) semakin tingginya keamanan kerja (jobsecurity); (3) meningkatkan kontrol terhadap work-lifeenvironment; (4) berkurangnya tingkat stres kerja; dan (5) semakin meningkatnya kesehatan fisik dan mental.

Pentingnya worklife balance dipertegas oleh hasil penelitian yang dilakukan oleh Redwood (2012), mengemukakan bahwa organisasi yang mendorong karyawan untuk memiliki keseimbangan yang baik antara pekerjaan dan keluarga akan memperoleh pendapatan per tahun $20 \%$ lebih besar per karyawan daripada organisasi yang tidak mendorong work-life balance. Dalam penelitian Bloom, Kretschmer, \& Van Reenen. (2006) mengatakan bahwa penerapan worklife balance pada organisasi akan meningkatkan kualitas manajemen pada organisasi tersebut. Peningkatan kualitas manajemen akan berdampak pada produktivitas dan kehidupan yang lebih baik pada karyawan mereka. Selanjutnya, Lockett (2008) mengemukakan bahwa penerapan keseimbangan kehidupan di rumah dan tempat kerja akan berakibat positif pada perusahaan. Perusahaan mendapatkan keuntungan dari keseimbangan yang dialami oleh karyawannya, antara lain: meningkatnya komitmen karyawan terhadap perusahaan, menurunnya tingkat turnover karyawan, menurunnya tingkat absen karyawan, meningkatnya kemampuan perusahaan dalam menarik dan merekrut staff, meningkatnya kesehatan dan keselamatan karyawan, menurunkan stres dan meningkatkan produktivitas.

Berdasar fakta tersebut, dapat disimpulkan bahwa worklife balance penting untuk diterapkan, dan hal tersebut tentunya tidak lepas dari peran serta individu dan organisasi. Peran serta individu dalam menerapkan worklife balance diantaranya kemampuan mengelola stress, manajemen waktu, dan relaksasi. Sedangkan peran serta organisasi dalam mendukung worklife balance dapat dilakukan dengan cara penerapan waktu yang ketat mengenai pulang kantor, libatkan para pekerja dalam kegiatan yang menyenangkan, serta hadirkan life motivator agar para pegawai bisa mengumpulkan kembali energinya. Kesuksesan suatu perusahaan tentunya tak lepas dari hasil kinerja setiap karyawan yang ada.

Penelitian yang dilakukan Studi New World of Work yang diselenggarakan oleh Microsoft terhadap bisnis yang melibatkan lebih dari 200 responden asal Indonesia memperlihatkan bahwa konsep tradisional tentang bekerja telah mengalami perubahan. Salah satunya adalah keseimbangan antara kehidupan pribadi dan kantor menjadi sebuah 
tantangan. Dimana 77\% responden Indonesia mengatakan keseimbangan antara kehidupan pribadi dan kantor menjadi aspek penting dari pekerjaan mereka namun hanya $47 \%$ responden yang merasa telah mencapai hal tersebut. Ditambah dengan pekerjaan yang tidak selesai tepat waktu pada pukul 17.00 sehingga mayoritas responden sebanyak 93\% mengatakan bahwa mereka tetap dituntut untuk dapat dihubungi di luar jam kantor agar bisa menyelesaikan tugas secara efisien (Alam, 2016).

Sedangkan penelitian yang dilakukan Jobstreet yaitu survei kepada 17.623 koresponden pada awal bulan Oktober tentang kepuasan kerja karyawan terhadap pekerjaan mereka. Dari hasil survei tersebut menunjukkan bahwa 73\% karyawan merasa tidak puas dengan pekerjaannya dikarenakan beberapa faktor. Hal ini berdampak serius pada penurunan produktivitas kerja hingga kecilnya jenjang karir (Jobstreet, 2014). Sebesar $85 \%$ koresponden juga mengaku bahwa mereka tidak memiliki Work-life balance (keseimbangan antara pekerjaan dan kehidupan pribadi). Survei Jobstreet.com pada bulan September 2014 bahkan menyebutkan bahwa 62\% karyawan mengaku sulit tidur karena masih memikirkan pekerjaannya. Padahal hasil penelitian yang dilakukan Morgan Redwood pada tahun 2014 di Inggris menyebutkan bahwa perusahaan yang mendorong karyawan untuk memiliki keseimbangan baik antara pekerjaan dan kehidupan pribadi akan memperoleh pendapatan pertahun $20 \%$ lebih besar daripada perusahaan yang tidak mendorong Work-life balance (Jobstreet, 2014).

Di ranah kerja, tidak adanya Work-life balance menyebabkan kinerja buruk dan absensi karyawan yang lebih banyak (Froneetal., 1997 dalam Kim, 2014), namun keseimbangan kerja dan kehidupan keluarga dikaitkan dengan peningkatan kepuasan kerja dan komitmen organisasi (Cegarra-Leivaetal, 2012; Wayne etal, 2004 dalam Kim, 2014). Gravesetal (2007) dalam Koubova dan Buchko (2013) meneliti efek dari komitmen peran keluarga pada sikap dan kinerja manajer, dan menemukan hubungan positif. Koubova dan Buchko (2013) tersebut menyatakan bahwa seseorang dapat mencapai kinerja yang lebih baik berkat sejumlah besar energi yang dirawat dan diperoleh dari "emosional tenang" yang tinggi tersebut dalam lingkup kegiatan pribadi. Singkatnya, peneliti tersebut mengasumsikan bahwa seseorang yang berkinerja baik dalam keluarga dan lingkup pribadi, dimana emosi cenderung lebih umum, mengarah kepada kepuasan yang tinggi untuk kehidupan pribadi yang pada akibatnya memungkinkan individu untuk berkinerja menjadi lebih baik dengan kemungkinan lebih besar dalam promosi dan kemajuan karir.

Dalam beberapa tahun terakhir, Work-life balance telah muncul dan menjadi topik yang berbeda dalam literatur kehidupan kerja (Greenhaus dan Allen, 2010 dalam Helmle, Botero, dan Seibold, 2014). Work-life balance telah ditetapkan dengan beberapa cara. Misalnya, Clark (2000) dalam Helmle, Botero, dan Seibold (2014) menggambarkan Work-life balance sebagai tingkat kepuasan yang individu rasakan ketika mereka bisa berfungsi di tempat kerja dan di rumah dengan minimal konflik peran. Grzywacz dan Carlson (2007) dalam Helmle, Botero, dan Seibold (2014) mendefinisikan Work-life balance sebagai pemenuhan harapan terkait peran yang dinegosiasikan dan dibagi antara individu dan mitra terkait peran mereka dalam domain pekerjaan dan keluarga. Greenhaus dan Allen (2010) dalam Helmle, Botero, dan Seibold (2014) mendefinisikan Work-life balance sebagai sejauh mana efektivitas individu dan kepuasan dalam peran pekerjaan dan keluarga yang kompatibel dengan prioritas peran kehidupan individu pada suatu titik waktu tertentu.

Adapun faktor-faktor yang mempengaruhi Work-life balance menurut Pouluse dan Sudarsan (2014) seperti faktor individual yaitu kepribadian. Ada 5 model besar kepribadian 
yaitu extraversion, agreeableness, conscientiousness, neuroticism, dan openness to experience. Lalu kesejahteraan yang dipengaruhi oleh dua komponen yaitu cognitive component life satisfaction dan affective component emotional well being. Kemudian terdapat emotional intelligence yang didefinisikan sebagai "kemampuan untuk menyesuaikan dan mengenali emosi atau perasaan, mengungkapkan emosi atau perasaan, mengatur emosi atau perasaan, dan mempergunakan emosi atau perasaan.

Sedangkan untuk faktor organisasional meliputi pengaturan kerja yang mudah disesuaikan dapat membantu karyawan untuk mencapai pencampuran yang lebih baik antara pekerjaan dan aktifitas di luar pekerjaan dan membantu organisasi merekrut, mempertahankan dan memotivasi karyawan. Salah satu yang paling penting adanya dukungan organisasi. Ada dua bentuk, yaitu dukungan formal dan dukungan informal. Dukungan formal dapat berupa ketersediaan work-family policies benefit dan fleksibilitas pengaturan jadwal kerja, sedangkan dukungan informal dapat berupa otonomi kerja, dukungan dari atasan dan perhatian terhadap karir karyawan. Faktor selanjutnya yaitu stres kerja juga dapat didefinisikan sebagai persepsi individu tentang lingkungan kerja seperti mengancam atau menuntut, atau ketidaknyamanan yang dialami oleh individu di tempat kerja. Adapun faktor konflik peran, ketidakjelasan peran dan roleoverload, lalu faktor kemajuan teknologi dapat membantu pekerjaan di kantor maupun pekerjaan rumah tangga sehingga sangat bermanfaat terhadap pengelolaan waktu.

Selanjutnya dari faktor lingkungan seperti pengaturan perawatan anak. Faktor keluarga yang berhubungan seperti jumlah anak dan tanggung jawab perawatan anak menyebabkan ketidakseimbangan dalam peran pekerjaan dan keluarga. Lalu faktor dukungan keluarga, dukungan pasangan, dukungan orang tua dan permintaan pribadi dan keluarga. Faktor sosial lainnya seperti umur, jenis kelamin, status perkawinan, status orangtua, pengalaman, tingkat karyawan, tipe pekerjaan, penghasilan serta tipe keluarga.

Menurut Lockwood (2003) Work-life balance adalah suatu keadaan seimbang pada dua tuntutan di mana pekerjaan dan kehidupan seorang individu adalah sama. Work-life balance dalam pandangan karyawan adalah pilihan mengelola kewajiban kerja dan pribadi atau tanggung jawab terhadap keluarga. Sedangkan dalam pandangan perusahaan Work-life balance adalah tantangan untuk menciptakan budaya yang mendukung di perusahaan di mana karyawan dapat fokus pada pekerjaaan mereka saat di tempat kerja.

Seringkali perusahaan memberikan jumlah tugas atau pekerjaan yang berlebihan yang mengakibatkan menurunnya produktivitas kerja pada karyawan. Hal tersebut menunjukkan bahwa seorang individu mengalami kesulitan untuk menyeimbangkan antara kehidupan pribadinya dan pekerjaannya. Ini menunjukkan bahwa work-life balance pada suatu perusahaan sangatlah penting. Perusahaan harus memperhatikan keseimbangan antara kehidupan pribadi dan kehidupan kerja karyawannya agar kepuasan kerja pada karyawan tetap terjaga. Faktor lain yang berpengaruh terhadap kepuasan kerja adalah pengembangan karir. Perencanaan dan pengembangan karir yang jelas dalam organisasi dapat meningkatkan motivasi kerja karyawan dalam melaksanakan pekerjaannya, sehingga menciptakan rasa puas dalam melaksanakan pekerjaannya (Nugroho \& Kunartinah, 2012).

Pentingnya work-life balance dipertegas oleh penelitian yang dilakukan oleh Ganapathi (2016), menunjukkan hasil bahwa semakin baik Work-life balance pada karyawan maka akan meningkatkan kepuasan kerja karyawan. Penelitian lain dikemukakan oleh McCrindle (Susi 
\& Jawaharrani, 2011) kepada 3000 orang Australia, menunjukkan bahwa Work-life balance adalah faktor utama daya tarik pekerjaan dan retensi, dimana mendorong Work-life balance dapat merangsang keterlibatan karyawan. Work-life balance adalah sejauhmana individu terlibat dan sama-sama merasa puas dalam hal waktu dan keterlibatan psikologis dengan peran mereka baik di dalam kehidupan kerja mauapun pribadi, serta tidak ada konflik diantara kedua peran tersebut (Westman, Brough, \& Kalliath, 2009)

Work-life balance merupakan cara yang dapat digunakan untuk membantu karyawan mengurangi konflik akibat peran ganda yang tidak seimbang. Menurut Delecta (2011) berpendapat bahwa work-life balance adalah sebagai kemampuan seseorang atau individu untuk memenuhi tugas dalam pekerjaannya dan tetap berkomitmen pada keluarga mereka, serta tanggungjawab di luar pekerjaan lainnya. Oleh karena itu, perusahaan tempat bekerja diharapkan membuat atau membentuk work-life balance agar pekerja atau karyawan dapat menyeimbangkan peran gandanya. Tidak hanya perusahaan saja yang diharapkan untuk membuat kebijakan work-life balance, akan tetapi karyawan seharusnya juga dapat menyeimbangkan perannya dan bekerja secara profesional agar keseimbangan kerja dapat terealisasi dengan baik.

Dari berbagai macam faktor-faktor yang mempengaruhi worklife balance, disebutkan dalam faktor organisasional dan faktor lingkungan adalah sebuah dukungan. Adanya dukungan organisasi, dukungan keluarga, dukungan pasangan dan dukungan orangtua adalah sebuah wujud dari sebuah dukungan sosial. Dukungan sosial bisa menjadi hal yang dapat mendorong pegawai untuk melaksanakan kewajibannya. Dukungan sosial bisa menjadi wadah bagi pegawai tersebut untuk mendapatkan dukungan berupa bantuan, informasi, maupun pemberian nasehat. Dengan dukungan sosial yang diberikan oleh pimpinan maupun rekan kerja, pegawai merasa diakui keberadaannya oleh lembaga tersebut. Pegawai juga bisa menyelesaikan pekerjaannya ketika mendapatkan dukungan dari pimpinan. Peran interpersonal pimpinan menjadi penting untuk mendorong hubungan yang positif dan meningkatkan kepercayaan diri pegawai tersebut (Leblebici, 2012).

Dari observasi awal peneliti, PT. PLN (Persero) merupakan suatu perusahaan yang bergerak dalam bidang jasa. Pemenuhan kebutuhan listrik kepada masyarakat yang sangat dibutuhkan untuk kehidupan sehari-hari menjadikan pelayanan yang optimal sebagai tugas dan visi dari perusahaan. Sebagaimana perusahaan BUMN lainnya diharapkan kinerja karyawan PT. PLN (Persero) efektif dan efisien. Gambaran umum dari fenomena yang dapat dilihat dari karyawan pada PT. PLN (Persero) adalah kenyamanan antar karyawan dalam bekerja, para karyawan seharusnya memiliki rasa bahagia dalam bekerja tidak hanya dalam mengerjakan pekerjaannya tapi juga bahagia berinteraksi dengan para karyawan lainnya. Fenomena di PT. PLN (Persero) masih ada beberapa karyawan yang merasa tidak mendapatkan keadilan diantara karyawan lain. Penjelasan fenomena diatas didukung oleh hasil wawancara dengan karyawan. Beberapa karyawan masih merasa dianak tirikan oleh tim. Beberapa karyawan masih merasa kurang nyaman dengan tim yang memiliki kondisi tersebut. Beberapa karyawan masih merasa kesulitan mendapatkan bantuan untuk menyelesaikan permasalahan didalam suatu pekerjaan. Beberapa karyawan merasa tidak mendapatkan bantuan, arahan dan saran yang diberikan oleh karyawan lainnya.

Dukungan sosial bermanfaat karena merupakan kebutuhan bagi seseorang, menurut Sarafino (dalam Lubis, 2009) mengatakan dukungan sosial mengacu pada kesenangan yang dirasakan, penghargaan akan kepedulian, atau membantu orang menerima dari orang-orang dan kelompok-kelompok lain. Menurut Ritler (dalam Smet, 1994) dukungan sosial mengacu 
pada bantuan emosional, instrumental, dan finansial yang diperoleh dari jaringan sosial seseorang. Larocco (dalam Hutabarat, 2000) menyatakan bahwa dukungan sosial dapat diartikan sebagai suatu dukungan emosional yang dapat menjadi penengah untuk penyelesaian suatu masalah. Melihat betapa pentingnya dukungan sosial yang diberikan pada setiap karyawan untuk mengatasi masalah pekerjaan maupun sekedar memberikan semangat kepada karyawan.

Sarason, dkk (1983) mengatakan bahwa individu dengan dukungan sosial tinggi memiliki pengalaman hidup yang lebih baik, harga diri yang lebih tinggi, serta pandangan hidup yang lebih positif dibandingkan dengan individu yang memiliki dukungan sosial yang lebih rendah. Dukungan sosial merupakan bantuan atau dukungan yang diterima individu dari orang-orang tertentu dalam kehidupannya dan berada dalam lingkungan sosial tertentu membuat si penerima merasa diperhatikan, dihargai, dan dicintai. Namun orang yang menerima dukungan sosial yang diberikan oleh orang lain. Mereka biasanya hanya memandang bahwa perhatian dari orang lain merupakan suatu dukungan bagi mereka. Dengan kata lain, dukungan sosial ini bersifat perseptif atau tergantung pada persepsi ini terhadap ketersediaan sumber dukungan (Kuntjoro, 2002).

Dari penjelasan diatas, fenomena yang dapat di lihat di PT. PLN (Persero) para karyawan merasa perlu adanya dukungan yang lebih tidak hanya dari lingkungan keluarga, seperti karyawan yang bekerja mendapatkan dukungan dari pasangan atau anak dalam pembagian waktu. Serta dukungan dari lingkungan kerja yang akan sangat membantu dalam meningkatkan kinerja mereka dan memberikan kenyamanan pada karyawan saat sedang bekerja. Terlihat ketika jam kerja karyawan PT. PLN (Persero) saling mereview pekerjaan masing-masing, walaupun mereka tidak bekerja dalam ikatan team tapi pekerjaan yang mereka lakukan tetap bersinambung satu sama lain. Jadi, keharusan dalam mengerjakan tugas tetap dilakukan bersama. Lingkungan yang mendukung akan membuat pekerjaan yang dilakukan lebih baik. Dukungan sosial yang terlihat disini lebih kepada tersistemnya cara para karyawan bekerja, yang membuat pekerjaan dapat selesai tepat waktu. Hal ini juga dapat dilihat dari hasil wawancara peneliti dengan karyawan. Beberapa karyawan biasanya selalu mereview kembali pekerjaan dengan rekan yang akan melanjutkan data yang telah disusun. Para karyawan berdiskusi tentang format dan kelanjutan dari planning maupun penyelesaian dari sebuah project, dan selanjutnya akan terus berhubungan ke bagian lain.

Fenomena diatas sesuai dengan faktor-faktor yang mempengaruhi dukungan sosial. Menurut Cohen \& Hoberman (1983) dukungan sosial mengacu pada berbagai sumber daya yang disediakan oleh hubungan antar pribadi seseorang. Dukungan sosial memiliki efek yang positif pada kesehatan, yang mungkin terlihat bahkan ketika tidak berada dibawah tekanan yang besar. Dukungan sosial menurut Cohen dan Hoberman (1985 dalam Rahman 2010) yaitu; (1) Appraisal support yaitu adanya bantuan yang berupa nasihat yang berkaitan dengan pemecahan suatu masalah untuk membantu mengurangi stresor; (2) Tangiable Support yaitu bantuan yang nyata yang berupa tindakan atau bantuan fisik dalam menyelesaikan tugas; (3) Self-Esteem Support yaitu dukungan yang diberikan oleh orang lain terhadap perasaan kompeten atau harga diri individu/perasaan seseorang sebagai bagian dari sebuah kelompok dimana para bagian dari sebuah kelompok dimana para anggotanya memiliki dukungan yang berkaitan dengan self-esteem seseorang; (4) Belonging Support yaitu 
menunjukkan perasaan diterima menjadi bagian dari suatu kelompok dan rasa kebersamaan.

Uchino (dalam Sarafino \& Smith, 2011) mendefinisikan dukungan sosial sebagai pemberian perasaan nyaman, perhatian, perasaan di hargai, atau penyediaan bantuan dari orang lain atau grup kepada seseorang. Dimensi dukungan sosial ada empat, yaitu: dukungan emosional atau penghargaan, dukungan nyata atau instrumental, dukungan informasi, dan dukungan persahabatan. Terdapat dua faktor yang mempengaruhi dukungan sosial, yaitu: faktor dari penerima dukungan (recipient) dan faktor dari pemberi dukungan providers.

Implikasi bagi individu dan organisasi adalah berusaha memfokuskan pada caracara untuk meningkatkan interaksi positif pekerjaan-keluarga sebagai alternatif mengurangi dampak negatif dari konflik pekerjaan-keluarga (McNall et al., 2009 ;Warner dan Hausdorf, 2009). Untuk pengembangan karir dan keseimbangan dalam hubungan keluarga beberapa aspek sumber daya yang diperlukan antara lain dukungan sosial profesional dan personal (Ezzedeen dan Ritchey, 2009). Dukungan sosial profesional diperoleh dari atasan, mentor, rekan kerja, dan orang lain yang ada dalam domain pekerjaan, sementara dukungan sosial personal diperoleh dari lingkungan keluarga seperti pasangan (suami/istri), anak-anak, orang tua/mertua, dan teman-teman.

Pentingnya pengkajian peranan dukungan sosial terhadap interaksi positif pekerjaan, keluarga dan keseimbangan hidup juga tidak terlepas dari kondisi riil yang nampak. Peningkatan jumlah wanita dalam angkatan kerja di Indonesia (43,5\% dari seluruh angkatan kerja), peningkatan jumlah pasangan karir ganda (dual-career family) dimana suami dan istri memiliki pekerjaan dan tanggung jawab keluarga sehingga mayoritas anak-anak tumbuh dengan kedua orang tua yang bekerja di luar rumah (Mondy, 2008) dan meningkatnya jumlah rumah tangga perorang tua tunggal akibat perceraian (hingga 2010, angka perceraian di Indonesia meningkat 70\%), merupakan tantangan dan peluang bagi organisasi untuk peka dan lebih fleksibel terhadap kebutuhan individu.

Dukungan sosial merupakan sumber daya yang penting dalam memperkaya hubungan peran pekerjaan dan keluarga, namun penelitian-penelitian tentang interaksi positif pekerjaan keluarga sebelumnya belum banyak mengeksplorasi peranan tersebut. Hasil-hasil penelitian sebelumnya lebih banyak mengeksplorasi anteseden interaksi positif pekerjaan-keluarga seperti karakteristik personal (pendidikan, pendapatan, gender, ras) dan stres (stres pekerjaan, stres keluarga), serta keterlibatan psikologis di tempat kerja dan rumah (Grzywacz dan Marks, 2000; Washington, 2006).

Terbatasnya hasil-hasil penelitian empiris yang menguji pengaruh dukungan sosial dengan interaksi positif pekerjaan-keluarga dan keseimbangan hidup, memungkinkan untuk mengkaji lebih lanjut peranan dukungan sosial yang secara logis membantu karyawan mengelola peran dalam domain pekerjaan dan keluarga. Selain itu, dukungan sosial telah digunakan sebagai anteseden dalam penelitian interaksi negatif pekerjaankeluarga (MdSidin et al., 2010; Namayandeh et al., 2010; Ryan et al., 2001), sehingga dukungan sosial yang dapat memberikan bantuan instrumental untuk membantu karyawan mengubah tuntutan pekerjaan dan keluarga yang saling bersaing menjadi saling memberikan manfaat, memungkinkan juga untuk digunakan dalam penelitian interaksi positif pekerjaan-keluarga. Penelitian Bhargava dan Baral (2009) menunjukkan dukungan sosial krusial untuk pengayaan pekerjaan-keluarga. 


\section{Work-life Balance}

Menurut Fisher (2009) mendefinisikan work-life balance sebagai upaya yang dilakukan oleh individu untuk menyeimbangkan dua peran atau lebih yang dijalani. Menurut Greenhaus et al.(2003) keseimbangan kehidupan-kerja adalah sejauh mana suatu individu terikat secara bersama di dalam pekerjaan dan keluarga, dan sama-sama puas dengan peran dalam pekerjaan dan peran dalam keluarganya. Menurut Lockwood (2003) Work-life balance adalah suatu keadaan seimbang pada dua tuntutan dimana pekerjaan dan kehidupan seorang individu adalah sama. Dimana Work-life balance dalam pandangan karyawan adalah pilihan mengelola kewajiban kerja dan pribadi atau tanggung jawab terhadap keluarga. Work-life balance berarti karyawan dapat dengan bebas menggunakan jam kerja yang fleksibel untuk menyeimbangkan pekerjaan atau karyanya dengan komitmen lain seperti keluarga, hobi, seni, studi, dan tidak hanya fokus terhadap pekerjaannya (Frame dan Hartog, 2003). Work-life balance memiliki konsekuensi penting bagi sikap karyawan terhadap organisasi mereka, serta untuk kehidupan karyawan (Scholarious dan Marks, 2004).

Empat komponen work-life balance seperti waktu, perilaku, ketegangan, dan energi menjadi dasar bagi Fisher (2009) dalam mengembangkan alat ukur Work-life balance. Pengembangan alat ukur tersebut menghasilkan item-item yang digolongkan menjadi empat dimensi (Nurlambang, 2016) yaitu : (1) WIPL (Work Interfence With Personal Life). Dimensi ini mengacu pada sejauh mana pekerjaan dapat mengganggu kehidupan pribadi individu. Misalnya, bekerja dapat membuat seseorang sulit mengatur waktu untuk kehidupan pribadinya; (2) PLIW (Personal Life Interfence With Work). Dimensi ini mengacu pada sejauh mana kehidupan pribadi individu mengganggu kehidupan pekerjaannya. Misalnya, apabila individu memiliki masalah di dalam kehidupan pribadinya, hal ini dapat mengganggu kinerja individu pada saat bekerja; (3) PLEW (Personal Life Enhancement Of Work). Dimensi ini mengacu pada sejauh mana kehidupan pribadi seseorang dapat meningkatkan performa individu dalam dunia kerja. Misalnya, apabila individu merasa senang dikarenakan kehidupan pribadinya menyenangkan maka hal ini dapat membuat suasana hati individu pada saat bekerja menjadi menyenangkan; (4) WEPL (Work Enhancement Of Personal Life). Dimensi ini mengacu pada sejauh mana pekerjaan dapat meningkatkan kualitas kehidupan pribadi individu. Misalnya, keterampilan yang diperoleh individu pada saat bekerja memungkinkan individu untuk memanfaatkan keterampilan tersebut dalam kehidupan sehari-hari.

\section{Dukungan Sosial (Social Support)}

Sarafino (2006) menyatakan bahwa dukungan sosial mengacu pada memberikan kenyamanan pada orang lain, merawatnya atau menghargainya. Menurut Quick dan Quick (1984), dukungan sosial dapat bersumber dari jaringan sosial yang dimiliki oleh individu yaitu dari lingkungan pekerjaan (atasan, rekan kerja, dan bawahan), lingkungan keluarga (pasangan, anak, saudara).

Dalam lingkungan pekerjaan, untuk dapat meningkatkan dan mengoptimalkan kerja para pegawai, maka pimpinan harus bisa menjalin hubungan dan komunikasi yang baik kepada para pegawainya. Menjalin hubungan tidak hanya sekedar rajin berkomunikasi dengan pegawai. Namun juga memberikan dukungan-dukungan sosial kepada pegawai. Dukungan sosial merupakan suatu bentuk kenyamanan fisik maupun psikologis yang diberikan oleh teman-teman maupun keluarga (Baron \& Byrne, 2000). 
Sarafino (1998) menguraikan beberapa dimensi dari dukungan sosial aspek yakni; (1) Aspek Emosional, meliputi ekspresi dari empati, kepedulian terhadap seseorang. Hal ini memberikan seseorang rasa nyaman, ketentraman hati, rasa memiliki, dan dicintai sewaktu mengalami masalah. (2) Aspek Instrumental, dukungan instrumental meliputi bantuan secara langsung sesuai dengan apa yang dibutuhkan oleh individu, misalnya memberikan pinjaman uang atau memberikan pekerjaan pada waktu mengalami stres. (3) Aspek Informatif, dukungan informatif meliputi bantuan seperti pemberian saran-saran, nasehat, petunjuk atau feedback yang didapatkan dari orang lain secara langsung, sehingga individu dapat mencari penyelesaian dari suatu masalah atau tekanan yang dihadapi. (4) Aspek Penghargaan, hal ini melalui ekspresi positif masyarakat kepada seseorang. Dorongan untuk sepakat dengan pemikiran seseorang atau perasaannya, dan pembandingan positif dari seseorang dengan orang lain, seperti kepada seseorang yang kurang mampu dan terpuruk. Dukungan semacam ini berguna membuat seseorang merasa dirinya berharga, mampu, dan dihargai. Dukungan harga diri ini sangat berguna dalam mengkaji stres. (5) Dukungan Kelompok sosial, bentuk dukungan ini akan membuat individu merasa menjadi anggota dari suatu kelompok yang memiliki kesamaan minat dan aktivitas sosial dengan kelompok. Dengan begitu individu akan memili perasaan senasib.

Jhonson dan Jhonson (2000) mengemukakan dua faktor yang mempengaruhi dukungan sosial. (1) Berdasarkan banyak kontrak sosial yang dilakukan individu, pengukuran dukungan sosial dalam hal ini dapat dilihat dari banyaknya terjadi kontak sosial dan interaksi hubungan dengan saudara-saudaranya atau teman-temannya, keanggotaan dalam suatu kegiatan keagamaan ataupun keanggotaan dalam organisasi yang bersifat formal maupun organisasi yang bersifat informal. (2) Berdasarkan keterdekatan hubungan dukungan sosial dalam hal ini didasarkan pada kualitas hubungan yang terjalin antara pemberi dan penerima dukungan, bukan berdasarkan kuantitas pertemuan. Sejauh mana jalinan antara pemberi dan penerima dukungan sosial, sebesar apa kualitas hubungan yang terjadi diantara pemberi dan penerima dukungan maka, akan semakin berdampak positif bagi terjadinya perubahan perilaku yang diharapkan dan dapat membantu individu penerima dukungan untuk keluar dari persoalan yang tengah menimpa dirinya.

\section{Dukungan Sosial dan Work-life balance}

Selain kesehatan fisik dan pola pikir, pada saat beradaptasi dengan kehidupan, seseorang juga dapat mencari dukungan dari orang lain. Dukungan tersebut dinamakan dukungan sosial (Social support). Hal paling penting dari suatu dukungan sosial yang diberikan adalah, seorang pegawai merasa diakui dan dihargai keberadaannya oleh lembaga tempat ia bekerja. Pegawai memiliki rekan bicara yang dapat membantu memberikan informasi dalam penyelesaian tugas-tugas, memiliki rekan untuk saling memberikan nasihat dalam pekerjaan, dan memiliki rekan yang dapat menghibur serta membangkitkan semangat saat melakukan pekerjaan.

Selain itu, dengan pemberian dukungan sosial ini, diharapkan nantinya pegawai akan memiliki sikap-sikap positif dalam melakukan pekerjaannya. Orang-orang dengan dukungan sosial yang baik berkemungkinan kecil untuk bereaksi secara negatif terhadap apa yang ia alami dalam kesehariannya, dibandingkan dengan orang-orang yang mendapat dukungan sosial sangat sedikit (Lahey, 2007). Dapat dilihat bahwa dukungan sosial dapat memberikan pengaruh terhadap produktivitas kerja pegawai.

Menurut Lazaretal dalam Valen (2017) manfaat keseimbangan kehidupan kerja (Work- 
life balance) bagi sebuah organisasi adalah mengurangi kemangkiran (absenteeism) dan keterlambatan (lateness), meningkatkan produktivitas dan organizational image, adanya komitmen dan loyalitas pegawai, meningkatnya retensi dari valuable employee, mengurangi biaya lembur dan berkurangnya tingkat turnover staff. Sedangkan, manfaat keseimbangan kehidupan kerja bagi karyawan adalah meningkatnya kepuasan kerja, semakin tingginya keamanan kerja (jobsecurity), meningkatnya control terhadap work-life environment, berkurangnya stres kerja, dan semakin meningkatnya kesehatan fisik dan mental karyawan.

Work-life balance sering disamakan dengan work-family balance karena keluarga merupakan bagian dalam kehidupan individu. Banyak organisasi menggunakan istilah work-life balance untuk pekerja yang bukan berstatus sebagai orangtua atau menikah, namun untuk pekerja yang menginginkan keseimbangan dalam pekerjaan dan kegiatan di luar pekerjaan seperti olahraga, wisata, dan studi. Sedangkan work-family balance digunakan untuk pekerja yang berstatus sebagai orang tua atau telah menikah yang menginginkan keseimbangan dalam pekerjaan dan keluarganya (Kalliath \& Brough, 2008).

Terdapat beberapa aspek yang menyusun work-family balance. aspek tersebut adalah (1) keseimbangan waktu yaitu waktu yang sama yang dihabiskan untuk bekerja dan menjalankan peran dalam keluarga, (2) keseimbangan keterlibatan yaitu tingkat keterlibatan psikologis yang sama dalam peran pekerjaan dan keluarga, dan yang terakhir adalah (3) keseimbangan kepuasan yaitu tingkat kepuasan yang sama dengan peran pekerjaan dan keluarga (Greenhaus, Collins \& Shaw, 2003).

Barnett dan Hyde (dalam Greenhaus, Collins, \& Shaw, 2003), mengemukakan manfaat tercapainya work-family balance bagi individu adalah dapat meningkatkan kualitas hidup individu, karena keterlibatan individu dalam beberapa peran dapat melindungi individu dari efek negatif salah satu peran dan mampu tanggap dalam menghadapi suatu tuntutan peran. Moore (2007), berpendapat bahwa pekerja yang mampu mencapai work-family balance menjadi setia dan berperilaku positif dalam bekerja. Parkes \& Langford (2008), lebih lanjut menjelaskan manfaat tercapainya work-family balance bagi pekerja adalah meningkatkan kesejahteraan, menurunkan stress pekerjaan dan burnout. Work-family balance juga meningkatkan kepuasan terhadap pekerjaan, komitmen organisasi, produktivitas, tingginya organisational citizenship behaviour, turunnya intensi turnover (Waltman \& Sullivan, 2007). Work-family balance yang memuaskan juga terkait dengan hasil di luar pekerjaan, seperti kehidupan, keluarga, perkawinan, adanya waktu luang dan urusan keluarga (Allen, 2001).

Maka dari itu, kedua keterkaitan di atas dapat disimpulkan bahwa social support diperlukan dalam suatu kehidupan bekerja dan pribadi, dimana dukungan sosial yang terlibat dalam kehidupan bekerja, bukan hanya berdampak pada kehidupan pribadi, namun berdampak pada kehidupan bekerja. Maka hipotesis dari penelitian ini adalah terdapat pengaruh positif social support terhadap work-life balance pada karyawan.

\section{METODE PENELITIAN}

Penelitian ini merupakan penelitian dengan pendekatan kuantitatif. Menurut Creswell (2014), penelitian kuantitatif mengharuskan peneliti untuk menjelaskan bagaimana variabel mempengaruhi variabel yang lain. Sugiyono (2012) metode eksplanasi adalah penelitian yang menjelaskan hubungan kausal antara variabel-variabel yang mempengaruhi hipotesis. Penelitian ini menggunakan pendekatan survei dengan mengambil sampel satu populasi dan menggunakan kuesioner. Sebagai alat pengambilan data pokok (Singarimbun, 1989). 
Teknik statistik regresi linier sederhana yaitu didasarkan pada hubungan fungsional ataupun kausal satu variabel independen dengan satu variabel dependen (Sugiyono, 2012).

Subjek dari penelitian ini adalah 100 orang yang bekerja di PT. PLN. Pengambilan subjek dari penelitian ini menggunakan teknik quota sampling. Quota sampling adalah teknik untuk menentukan sampel dari populasi dengan jumlah (kuota) yang ditentukan (Sugiyono, 2001). Peneliti menggunakan Teknik kuota sampling dan memberikan batasan 100 karyawan untuk menjadi subjek penelitian. Jumlah sampel yang ditentukan 100 orang, jika pengumpulan data belum memenuhi kuota 100 orang tersebut, maka penelitian dipandang belum selesai.

Subjek yang digunakan dalam penelitian ini minimal memiliki masa kerja satu tahun di perusahaan PT. PLN. Mengacu pada teori Fieldman \& Arnold (1983) yang menyatakan bahwa seorang karyawan yang telah bekerja antara satu sampai tiga tahun cenderung telah dipengaruhi oleh lingkungan, aturan, nilai, dan tujuan perusahaan yang akan membentuk sikap baru sesuai dengan kondisi lingkungan kerja. Subjek dalam penelitian ini berjumlah 100 orang karyawan terdiri 55 laki-laki dan 33 perempuan. Dari beberapa divisi dalam perusahaan, bertempat di Kota Malang. 12 orang lainnya tidak mencantumkan jenis kelamin. Untuk lebih jelasnya dapat dilihat pada tabel di bawah ini.

Tabel 1. Deskripsi Subjek Penelitian

\begin{tabular}{ccc}
\hline Kategori & Frekuensi & Persentase \\
\hline $\begin{array}{c}\text { Jenis Kelamin } \\
\text { Laki-Laki }\end{array}$ & 55 & $55 \%$ \\
Perempuan & Responden & \\
& 33 & $33 \%$ \\
Tidak Ingin Mencamtumkan & Responden & \\
& 12 & $12 \%$
\end{tabular}

Berdasarkan landasan teori serta rumusan hipotesis penelitian yang ada, terdapat dua variabel yang akan diteliti yaitu: variabel bebas atau variabel X (Independent variable) adalah dukungan sosial (Social support) dan variabel terikat atau variabel Y (dependent variable) adalah Work-life balance.

Definisi dukungan sosial (social support) yaitu dukungan yang didapatkan dari orang lain sehingga menimbulkan perasaan bahagia, nyaman, dihargai, diperhatikan, dicintai, dan merasa terbantu bagi individu yang menerimanya.Untuk mengukur dukungan sosial, peneliti mengadopsi skala penelitian dari skala model Likert yang disusun oleh Adrian (2014) yang menggunakan teori Sarafino (1998) yang meliputi aspek (1) Dukungan emosional, (2) Dukungan penghargaan, (3) Dukungan instrumental, (4) Dukungan informasi, dan (5) Dukungan kelompok sosial, skala tersebut berjumlah 33 item dengan nilai CronbachAlpha 0,909 $(\alpha>0,6)$ dari 33 item tersebut meliputi dukungan emosional berjumlah 7 item, dukungan penghargaan berjumlah 4 item, dukungan instrumental berjumlah 6 item, dukungan informasi berjumlah 8 item dan dukungan kelompok sosial 8 item.

Sedangkan definisi Work-life balance yakni keseimbangan antara kehidupan kerja dan kehidupan pribadi karyawan ataupun pegawai agar dapat berjalan dengan harmonis, 
seperti menyeimbangkan atau menyelaraskan waktu, perilaku, ketegangan, serta energi pegawai dalam bekerja. adalah skala work life balance (WLB) dari Fisher, Bulger \& Smith (2009) yang terdiri dari 17 item. Hasil skala WLB yang dilakukan pada 100 pekerja diperoleh ke 17 item valid dengan nilai validitas sebesar 0,31-0,50 serta nilai realibilitas 0,812, dimana item ini merupakan turunan dari dimensi pembentuk work life balance yaitu work interference personal life, personal life interference work, personal life enchancemen of work, dan work enchancement of personal life.

Teknik pengumpulan data yang digunakan kedua instrumen dengan menggunakan konsep (favorable) dan item yang tidak mendukung konsep (unfavorable). Setiap item memiliki empat pilihan jawaban: Sangat Setuju (SS), Setuju (S), Tidak Setuju (TS), dan Sangat Tidak Setuju (STS). Dapat dirincikan sebagai berikut: pada item favorable sangat setuju diberi nilai 4 dan pada item unfavorable diberi nilai 1, setuju pada favorable diberi nilai 3 dan pada item unfavorable diberi nilai 2, tidak setuju pada favorable diberi nilai 2 dan pada unfavorable diberi nilai 3, dan sangat tidak setuju pada favorable diberi nilai 1 dan pada unfavorable diberi nilai 4.

Hasil try out pada variabel dukungan sosial dan work-life balance untuk pengujian validitas dan reliabilitas instrumen didapatkan hasil sebagaimana tabel berikut.

Tabel 2. Indeks Validitas dan Reliabilitas Alat Ukur Penelitian

\begin{tabular}{lccc}
\hline Alat Ukur & $\begin{array}{c}\text { Jumlah } \\
\text { Item } \\
\text { Valid }\end{array}$ & Indeks Validitas & $\begin{array}{c}\text { Nilai } \\
\text { Reliabilitas } \\
\text { (Crobach's } \\
\text { Alpha })\end{array}$ \\
\hline Skala dukungan sosial & 28 & $0,339-0,665$ & 0,909 \\
\hline Skala work-life balance & 17 & $0,310-0,500$ & 0,812 \\
\hline
\end{tabular}

Dalam pelaksanaan penelitian ini tedapat tiga prosedur antara lain, tahap pertama persiapan awal dengan berdiskusi permasalahan kepada dosen pembimbing satu dan dua. Kemudian peneliti melakukan studi pendahuluan, perumusan masalah, penentuan kajian teori dan hipotesis, menentukan variabel beserta sumber data, serta menentukan instrumen penelitian. Setelah itu penelitian melakukan seminar proposal yang sebelumnya telah disetujui oleh dosen pembimbing satu dan dua sebagai acuan perijinan turun lapang. Penelitian melakukan uji coba atau tryout dengan jumlah subjek tryout 100 subjek. Sapnas dan Zeller dalam de Winter et al, (2009) berpendapat bahwa ukuran sampel 50-100 cukup memadai untuk mengevaluasi sifat psikometrik pada ukuran konstruk sosial.

Tahap kedua, peneliti melakukan penyebaran skala. Peneliti memberikan dua skala sekaligus kepada subjek penelitian yang telah ditentukan. Roscoe dalam Sugiyono (2012) menjelaskan bahwa sampel yang layak dalam penelitian adalah berkisar antara 30 sampai dengan 500.

Tahapan ketiga adalah peneliti melakukan entry data dan analisis dari ke 100 subjek terkait hasil kedua skala yang telah disebarkan menggunakan metode regresi linier sederhana. Peneliti menggunakan program bantu perhitungan berupa statistik SPSS for 
windows versi 21 . Kemudian dari hasil penelitian tersebut dilakukan analisa data dengan regresi linier sederhana.

\section{HASIL PENELITIAN}

Berdasarkan hasil pengujian menggunakan statistik menunjukkan nilai rata-rata (Mean) dan nilai standart deviasi (SD) masing-masing variabel sebagai berikut.

Tabel 3. Deskripsi Data Penelitian

\begin{tabular}{cccc}
\hline No & Variabel & Mean & SD \\
\hline 1 & Social Support $(\mathrm{X})$ & 90,92 & 8,671 \\
2 & Work-life Balance & 50,01 & 5,132 \\
& $(\mathrm{Y})$ & & \\
\hline
\end{tabular}

Melalui hasil uji statistik didapatkan hasil bahwa terdapat nilai mean (M) dan standart deviasi pada variabel social support $(\mathrm{X})$ dan work-life balance $(\mathrm{Y})$. Variabel social support $(\mathrm{X})$ memiliki rata-rata $(\mathrm{M}=90.92 ; \mathrm{SD}=8.671)$, dan variabel work-life balance $(\mathrm{Y})$ memiliki rata-rata $(\mathrm{M}=50.01$; $\mathrm{SD}=5.132)$.

Selanjutnya adalah pendataan terhadap keseluruhan responden, berikut merupakan kategori skor social suport dan work-life balance, yang akan dijelaskan pada tabel dibawah ini.

Tabel 4. Kategorisasi Social Support dan Work-life Balance

\begin{tabular}{llll}
\hline Variabel & Median & Kategori & Jumlah \\
\hline Social Support & 90,00 & Tinggi & 52 \\
& & Rendah & 48 \\
\hline & & \\
\hline Variabel & Median & Kategori & Jumlah \\
\hline Work-life Balance & 49,00 & Tinggi & 56 \\
& & Rendah & 44 \\
\hline
\end{tabular}

Uji hipotesis dilakukan menggunakan uji regresi linier sederhana. Penggunaan teknik dikarenakan berdasarkan uji asumsi mendapat hasil bahwa pengaruh social support dengan work-life balance bersifat tidak linear akan tetapi persebaran data variabel normal. Berdasarkan perolehan data penelitian, maka uji hipotesis penelitian sebagai berikut:

Tabel 5. Uji Normalitas Kolmogorov-Smirnov

\begin{tabular}{ccc}
\hline Variabel & Taraf Signifikan & Keterangan \\
\hline $\begin{array}{l}\text { Dukungan Sosial } \\
\text { Work-life Balance }\end{array}$ & 0,146 & Normal \\
\hline
\end{tabular}

Berdasarkan tabel One Sample Kolmogorov-Smirnov Test, diketahui nilai Signifikansi sebesar 0.146 dimana lebih besar dari 0.05 sehingga dapat dikatakan bahwa data penelitian normal.

Tabel 6. Deskripsi Uji Pengaruh Variabel $X$ terhadap Variabel $Y$

\begin{tabular}{ccccc}
\hline Variabel & Koefisien & $\mathbf{R}^{2}$ & Sig & Keterangan \\
\hline $\begin{array}{l}\text { Dukungan Sosial } \\
\text { Work-life Balance }\end{array}$ & 0,495 & 0,245 & & \\
\hline
\end{tabular}


Berdasarkan tabel Model Summary, diketahui bahwa Nilai Korelasi (R) sebesar 0.495 yang artinya koefisien regresi antara variabel dukungan sosial (social support) terhadap work-life balance sebesar 0.495, dan dijelaskan juga Koefisien Determinasi $\left(\mathrm{R}^{2}\right)$ sebesar 0.245 yang mengandung pengertian bahwa pengaruh variabel dukungan sosial (social support) terhadap work-life balance adalah sebesar $24,5 \%$, sedangkan sisanya dipengaruhi oleh variabel yang lain.

\section{DISKUSI}

Penelitian ini menunjukkan terdapat pengaruh antara dukungan sosial dengan worklife balance pada karyawan. Hal tersebut dapat dibuktikan dengan hasil dari analisa data yang telah peneliti lakukan yakni nilai sig. regresi sebesar $0.000<0.05$ menunjukan hasil bahwa terdapat pengaruh yang signifikan. Sehingga dapat disimpulkan bahwa dukungan sosial (social support) memberikan kontribusi sebesar 24,5\% terhadap work-life balance. Hasil dari penelitian ini memberikan bukti bahwa hipotesa yang menyatakan bahwa terdapat pengaruh antara dukungan sosial (social support) terhadap work-life balance diterima. Sehingga dengan terbuktinya hipotesa menjelaskan bahwa dukungan sosial (social support) menjadi salah satu faktor work-life balance. Hasil penelitian ini menunjukkan bahwa dukungan sosial memiliki kontribusi sebesar $24,5 \%$ terhadap worklife balance. Hal tersebut menunjukkan bahwa dukungan sosial dapat meningkatkan dimensi PLEW (Personal Life Enhancement Of Work). Dimensi ini mengacu pada sejauh mana kehidupan pribadi seseorang dapat meningkatkan performa individu dalam dunia kerja. Misalnya, apabila individu merasa senang dikarenakan kehidupan pribadinya menyenangkan maka hal ini dapat membuat suasana hati individu pada saat bekerja menjadi menyenangkan.

Dukungan sosial menjadi suatu bentuk kenyamanan fisik maupun psikologis yang diberikan oleh teman-teman maupun keluarga (Baron \& Byrne,2000), sehingga kenyamanan inilah yang menimbulkan rasa semangat bagi pegawai dalam melakukan pekerjaan. Gottlieb (dalam Smet, 1994) menyatakan bahwa dukungan sosial terdiri dari informasi atau nasehat verbal maupun non verbal, bantuan nyata atau tindakan yang didapatkan karena adanya kehadiran orang lain dan mempunyai manfaat emosional atau efek perilaku bagi pihak penerima. Dalam hal ini, individu dengan dukungan sosial yang tinggi mungkin memiliki seseorang yang dapat membantu dirinya untuk memberikan bantuan atau solusi terhadap masalah yang sedang ia hadapi. Ketika dihadapkan dalam sebuah permasalahan, ia tidak melihat situasi tersebut sebagai situasi yang penuh stress. Sehingga, tidak akan mengganggu kinerja dari pegawai tersebut. Inilah manfaat emosional yang dapat membuat produktivitas kerja pegawai menjadi tinggi. Hal ini diperkuat dengan model buffering effect oleh Sarafino (2002). Buffering effect ini dapat menjelaskan bagaimana dukungan sosial bisa mempengaruhi kondisi fisik dan psikologis individu. Dengan model ini dukungan sosial berperan sebagai pelindung dari efek negatif yang timbul dari tekanan-tekanan yang dialami dari lingkungan sekitar. Dukungan sosial bekerja dengan tujuan untuk memperkecil pengaruh dari tekanantekanan atau stress yang dialami individu.

Perilaku saling mendukung dan membantu satu sama lain di dalam sebuah lingkungan kerja, merupakan salah satu wujud dari dukungan sosial itu sendiri (Strauss \& Sayless, 1990). Pegawai yang berada pada lingkungan kerja memerlukan dukungan moral dari rekan kerja maupun pimpinannya. Hal itu membuktikan bahwa seorang pegawai akan 
selalu membutuhkan pegawai lainnya untuk dapat menjalankan dan mengerjakan pekerjaan maupun aktivitas dalam kesehariannya. Proses bantuan yang saling diberikan itulah yang nantinya akan dapat membantu mengurangi stress kerja pegawai. Dalam penelitian yang dilakukan oleh Almasitoh (2011), menunjukkan bahwa terdapat hubungan yang signifikan antara dukungan sosial dan stress kerja. Hasil penelitian ini diperkuat oleh pernyataan Gibson, Invancevivh, dan Donnely (1994) bahwa stress kerja ini dapat dipengaruhi oleh kondisi dalam sebuah organisasi, hubungan yang kurang baik antar rekan kerja, dan tuntutan kerja yang berakibat turunnya konsentrasi kerja dan kinerja yang kurang memuaskan karena kurangnya dukungan sosial di lingkungan tempat ia bekerja (Luthans, 1998).

Menurut Hodson (1997), dukungan sosial yang diberikan oleh rekan kerja atau pimpinan di dalam lingkungan kerja dapat memberikan kontribusi bagi produktivitas dan kesejahteraan karyawaan. Untuk itu, dengan adanya dukungan sosial, dapat membantu mengurangi tingkat stress kerja pegawai saat bekerja, sehingga produktivitasnya dalam bekerja dapat meningkat. Anoraga (1998) menyatakan bahwa penambahan stress cenderung tidak akan menghasilkan kemajuan pada produktivitas kerja. Jika stress kerja bertambah terus menjadi tinggi maka produktivitas kerja akan menurun, pegawai akan kehilangan untuk menghadapi masalah dalam pekerjaan, serta susah dalam mengambil keputusan. Disinlah peran dukungan sosial bekerja. Dukungan emosional menurut Wanberg (2000) merupakan dukungan sosial yang melibatkan seseorang memiliki hubungan sosial yang positif kepada rekan kerja ataupun atasan di dalam sebuah perusahaan. Adanya hubungan yang positif itulah yang membuat pegawai nyaman untuk bekerja, dan dapat membantunya untuk menyelesaikan permasalahan yang terjadi di dalam pekerjaan, sehingga stress kerja dapat teratasi.

\section{SIMPULAN DAN IMPLIKASI}

Berdasarkan pada hasil penelitian dapat disimpulkan mengenai hipotesis penelitian telah diterima, dengan adanya pengaruh positif dukungan sosial (social support) terhadap worklife balance. Hasil tersebut menunjukkan bahwa dukungan sosial merupakan salah satu faktor yang mendukung terbentuknya worklife balance. Keterkaitan dari penelitian yang sudah dilakukan berhubungan langsung dengan organisasi atau perusahaan yang menjadi salah satu pendukung terciptanya suasana lingkungan kerja yang baik dan berdampak pada produktivitas maupun peningkatan motivasi bagi para karyawan didalam suatu perusahaan.

Salah satunya dengan adanya dukungan sosial yang baik maka diharapkan dapat meminimalisir situasi yang mengakibatkan karyawan merasakan ketidaknyamanan saat bekerja. Dengan adanya dukungan yang diberikan pada karyawan akan sangat berpengaruh pada worklife balance yang dimiliki oleh karyawan. Karyawan juga salah satu faktor kesuksesan dalam membangun sebuah perusahaan yang mampu bersaing dan meningkatkan optimalisasi kinerja perusahaan. Bagi peneliti selanjutnya diharapkan dengan adanya penelitian ini dapat dijadikan sebuah referensi, apabila ingin melakukan penelitian selanjutnya dengan subjek dan tempat yang berbeda maupun dalam mengembangkan penelitian dengan variabel-variabel lainnya sehingga mampu meningkatkan worklife balance.

\section{REFERENSI}

Abendroth, A.-K., \& den Dulk, L. (2011). Support for the work-life balance in Europe: the 
impact of state, workplace and family support on work-life balance satisfaction. Work, Employment and Society, 25(2), 234-256. https://doi.org/10.1177/0950017011398892

Adrian, A. (2014). Hubungan Dukungan Sosial Dengan Burnout Pada Perawat Instalasi Gawat Darurat Di Rumah Sakit Banda Aceh. Skripsi. Program Sarjana Universitas Syiah Kuala, Banda Aceh.

Alam, K.S. (2016). Studi New World of Work Tunjukkan Pentingnya Transformasi Tempat Kerja bagi Peningkatan Produktivitas dan Daya Saing Bisnis di Indonesia. Diakses dari https://news.microsoft.com/id-id/2016/03/04/studi-new-world-of-work-tunjukkanpentingnya-transformasi-tempat-kerja-bagi-peningkatan-produktivitas-dan-dayasaing-bisnis-di-indonesia/.

Baron, R. A., \& Donn, B. (2000). Social psychology edisi ke 9. USA: Allyn \& Bacon.

Brough, P., Holt, J., Bauld, R., Biggs, A., \& Ryan, C. (2008). The ability of work-life balancepolicies to influence key social/organisational issues. Asia Pacific Journal of Human Resources, 46 (3), 261-274.

Clutterbuck, D. 2003. Managing Work-life Balance. London: Chartered Institute of Personnel and Development, CIPD House.

Cohen, She, Denldon., \& Hoberman, Harry M. (1983). Positive Events and Social Support as Buffer of Life Change Stress. Journal of Applied Social Psychology, 13, 99-125. Diakses dari http://www.psy.cmu.edu/-schohen/ISEL.

Creswell John.W. (2014). Penelitian Kualitatif \& Desain Riset. Yogyakarta:Pustaka Pelajar.

De Winter et al. (2009). Exploratory Factor Analysis with Small Sample Sizes. Department of BioMechanical Engineering, Faculty of Mechanical,Maritime and Materials Engineering, Delft University of Technology, The Netherlands. Multivariate Behavioral Research, 44:147-181, ISSN: 0027-3171 print/1532-7906 online. DOI: 10.1080/00273170902794206.

Ganapathi, Made dan Alini Gilang. (2016). Pengaruh Work-life Balance Terhadap Kepuasan Kerja Karyawan (Studi Pada PT. Bio Farma Persero). Bandung : Universitas Telkom.

Greenberg, J.S. 2004. Comprehensive Stres Management. New York: The McGraw-Hill Companies.

Greenhaus, J. H. dan N. J. Beutell. (1985). Sources of Conflict between Work and Family Roles. Academy of Management Review 10(1): 76-88.

Greenhaus, J. H., Collins, K. M., \& Shaw, J. D. (2003). The relation between work-family balance and quality of life. Journal of Vocational Behavior, 63, 510-531.

Grzywacz, J. G. dan N. F. Marks. (2000). Reconceptualizing the Work-Family Interface: An Ecological Perspective onthe Correlates of Positive and NegativeSpillover between Work and Family. Journal of Occupational Health Psychology 5: 111-126.

Helmle, J. R., Botero, I.C., \& Seibold, D.R. (2014). Factors That Influence Perceptions of WorkLife Balance in Owners of Copreneurial Firms. Journal of Family Business Management, 4, 110-132.

Jia, M., \& Mirit, S. (2012). Communication motives, satisfaction, and social support in the workplace: are supervisor effective support sources in employee networks?. Hawaii International Conference on System Sciences. Computer Society, 978-076945257.

JobStreet. (2014). 73\% Karyawan Tidak Puas dengan Pekerjaan Mereka. Diunduh dari http://www.jobstreet.co.id/career-resources/73-karyawan-tidak-puas-denganpekerjaan-mereka/\#.WtgZ69CyTqB. Diakses pada 18 Oktober 2019. 
Johnson, D.W., \& Johnson, F.P. (2000). Joining together: group theory and group skill (7th Ed).New Jersey : L Prentise Hall.

Kalliath, T. Brough, P. (2008). Work life balance: A review of the meaning of the balance construct. Journal of Management \& Organization, 14, 323-327.

Kim, H. S., Shereman, D..K. dan Taylor, S.E. (2008). Culture and Social Support. American Psycologist: Journal of The American Psychological Association Vol. 63 No. 6, September 2008.

Kucharova, V. (2009). Work-life balance: Societal and private influences. Sociologickýčasopis/Czech Sociological Review, 45 (06), 1283-1310.

Koubova, V., \& Buchko, A.A. (2013). Life-work Balance: Emotional Intelligence As A Crucial Component of Achieving Both Personal Life and Work Performance. Management Research Review, 36, 700-719.

Lahey, B.B. (2007). Psychology: an introduction, ninth edition. New York: The McGrawHill Companies.

Leblebici, D. (2012). Impact of workplace quality on employee's productivity: case study of a bank in turkey. Journal of Bussines, Economics \& Finance, 1 (1), 111-132.

Lockett, K. 2008. Work/Life Balance for Dummies. Australia: Wiley Publishing Australia Pty Ltd.

Lockwood, N.R. (2003). Work/Life Balances : Challenges And Solutions. HR Magazine, Alexandria 48(6):S1.

Marcinkus, W. C., Whelan-Berry, K. S., \& Gordon, J. R. (2007). The relationship of social support to the work-family balance and work outcomes of midlife women. Women in Management Review, 22(2), 86-111.

McNall, L. A., J. M. Nicklin, dan A. D. Masuda. (2009). A Meta-Analytic Reviewof the Consequences Associated withWork-Family Enrichment. Journal of Business and Psychology 25(3): 381-396.

Mondy, R. W. (2008). Manajemen Sumber Daya Manusia. Edisi ke-10. Erlangga. Jakarta

Namayandeh ,Hajar., Siti Nor Yaacob, dan Rumaya Juhari. 2010. The Influences of work support and family support on Work-Family Conflict (W-FC) Among Married Female Nurses in Shiraz-Iran. Journal of American Science. 6(12): h: 534-540.

Nugroho, D., \& Kunartinah. (2012). Analisis Pengaruh Kompensasi dan Pengembangan Karier terhadap Kepuasan Kerja dengan Mediasi Motivasi Kerja. Jurnal Bisnis dan Ekonomi Vol.19, No.2.

Poulose, S., \& N, Sudarsan. (2014). Work-life Balance: A Conceptual Review. International Journal of Advances in Management and Economics. Vol. 3 Issue. 2, 5-9.

Sarafino, E.P. (1998). Health Psychology: Biopsychologycal Interaction Third Edition. New York: John Wiley \& Sons, Inc.

Sarafino, E. P. (2006). Health Psychology : Biopsychosocial Interactions. Fifth Edition. USA: John Wiley \& Sons.

Sarafino, P. E., \& Smith, W. T. (2011). Biopsychosocial interaction seventh edition. Health psychology. Amerika Serikat: John Wiley \& Sons, INC.

Singarimbun, M., Effendi, S. (1989). Metode penelitian survei. Jakarta: LP3ES.

Sugiyono. 2012. Metode Penelitian Bisnis. Bandung : Alfabeta.

Susi, S. \& Jawaharrani, K. (2011). Work-life balance: the key driver of employee engagement. Asian Journal of Management Research. 2(1), 474-483.

Quick, J.C., \& Quick, J.D. (1984). Organizational stress and preventive management. New York: McGraw-Hill. 
Voydanoff, P. (2004). The effects of work demands and resources on work-to-family conflict and facilitation. Journal of Marriage and the Family, 66, 398-412.

Westman,M., Brough, P., \& Kalliath, T.(2009). Expert commentary on work-life balance and crossover of emotions and experiences: theoritical and practice advancements. Journal of Organizational Behavior. 30, 587-595. Doi: 10.1002/job.616.

Yanita \& Zamralita. (2001). Persepsi perempuan primipara tentang dukungan sosial suami dalam usaha menanggulangi gejala depresi pasca salin. Phronesis, 3(5). 
WORK-LIFE BALANCE, SOCIAL SUPPORT, EMPLOYEE 